\title{
Social Creativity and Place (Re)production: Tarbiat Pedestrian Route in Tabriz, Iran
}

\author{
Behnaz Aminzadeh ${ }^{1} \odot$, Razieh Rezabeigisani ${ }^{2} \odot$ \\ 1 Faculty of Urban Planning, University College of Fine Arts, University of Tehran, Enghelab Ave., Tehran, Iran (Principal \\ contact for editorial correspondence), Email: bgohar@ut.ac.ir \\ 2 Faculty of Urban Planning, University College of Fine Arts, University of Tehran. Email: r.rezabeighi@ut.ac.ir
}

\begin{abstract}
Purpose

This article explores the role of creativity and its aspects in urban environments by tackling the issue of place (re)production based on a particular interpretation of creativity as an "everyday" and "social" phenomenon. The paper gives theoretical evidence for the relationship between place (re)production and social aspects of creativity.

Design/Methodology/Approach

The study benefited from a review on both subjects of social creativity and place (re)production to find out their relationship and how they can be expressed in an urban space design process. Tarbiat pedestrian route in Tabriz, Iran was chosen as a case study. Based on the proposed conceptual model, a thematic content analysis was carried out on the qualitative data collected in 2019 from the Tarbiat pedestrian route using Atlas.ti.06 software with regard to the dimensions of creative (re)production of place.

\section{Findings}

The main achievement of this article is development of an original conceptual framework for applying 1) social creativity as an effective factor in (re)production of place, and 2) the findings in a practical context.

\section{Research Limitations/Implications}

The main limitations of this research include the time constraints of accomplishing a qualitative research, the limited number of previous studies on the topic and the lack of samples qualifying as a case study.

\section{Social/Practical Implications}

This article is based on the concept of creativity as a social phenomenon that involves ordinary, unplanned, and collective creative acts of individuals, as well as urban place formation as a sociospatial process, in which social context plays an important role. Also, according to the results, incentives of social creativity in the (re)production of the place are closely associated with the active role of the users and their enthusiasm to participate in design processes.

\section{Originality/Value}

This research focuses on an urban regeneration initiative to show how an appropriate context for mobilizing actors, bringing them together and shaping a more creative urban space is achieved by conscious level of place (re)production through inspired and gradual expert-oriented interventions, and the unconscious level of (re)production through the everyday shared experiences of people.
\end{abstract}




\section{INTRODUCTION}

The subject of the built environment and its relations to the creativity has been discussed in different academic fields, e.g. environmental psychology (Amabile, Conti, Coon, Lazenby, \& Herron, 1996; Hemlin, Allwood \& Martin, 2004), sociology (Barlow, 2000; Burns, Corte, \& Machado des Johansson, 2015), and urban studies (Drake, 2003; Florida, 2002; Landry, 2012). Scholars have introduced cities as a suitable context for creativity (Florida \& Tinagli, 2004; Howkins, 2001) and "places" as the integral part of creative strategies, as expressed in the ideas of creative industries (Hartley, 2005; Howkins, 2001), the creative economy (Florida, 2002; Florida \& Tinagli, 2004) and the creative city (Drake, 2003; Landry, 2012). The success and development of cities depend on organization of the common creativity by urban authorities (Florida, 2002). The claim that creativity is the result of the social interaction among people is not a new claim, but different aspects of the connections between creativity and the production of the built environments in the context of urban design have not been studied to an acceptable degree thus far. Most of what is promoted in design is arguably the individual creativity of designers or a group of elites (Akin, 1978; Gero, 1990; Lawson, 2005), which leads to adapting exclusive approaches to the subject of creativity.

Bourdieu (1993) considers the place of artwork in the social conditions that produce them, and Putnam (1993) draws attention to the "social capital" and the importance of relationships between individuals and their impact on realizing creative potential. Thus, groups and communities, as well as individuals, can produce creative products (Barlow, 2000; Kasl, Marsick, \& Dechant, 1997; Watson, 2007). Likewise, social institutions have features and environments that encourage creative behaviors (Robinson \& Stern, 1997).

Much human creativity arises from activities that take place in a social context in which interaction with other people embodies the group knowledge. Creativity does not happen inside a person's head, but in the interaction between a person's thoughts and the socio-cultural context (Csikszentmihalyi, 1996). Scott (2006) and Ho (2009) believe that the relationship between the place and the creative production requires understanding the situated design processes associated with the specific production.

This study identifies a gap by reviewing the literature on the understanding of creativity as a social phenomenon and the process of place production in design. To fill this gap, a theoretical study and an experimental survey were needed to answer the questions missing in the literature on place and creativity and expand understanding of the place production process and how social creativity contributes to it.

In order to measure the experimental model of creative place reproduction in the urban environment, the regeneration of Tarbiat pedestrian route located in District 8 of Tabriz city, Iran was selected. 
Social Creativity and Place (Re)production: Tarbiat Pedestrian Route in Tabriz, Iran

The main reasons for choosing the regeneration project of Tarbiat pedestrian route are briefly listed below:

- The Tarbiat regeneration project is a significant example of designoriented urban projects implemented recently in Iran based on placemaking goals and gradual process.

- The historical, social, and cultural features of Tarbiat as a vibrant public place with multiple uses and activities in various scales that strengthen urban life are necessary for the research analysis.

The qualitative methodology of the research is based on conducted indepth interviews and thematic content analysis through Atlas.ti.06 drawing on the common characteristic of "everyday creativity," as well as the role of collective efforts in the processes of place (re)production.

\section{LITERATURE REVIEW}

\section{Social and Everyday Creativity}

Creativity is one of the main concepts in art and related fields, as well as psychology and sociology. It is defined as the use of mental abilities to create or develop new thoughts or concepts (e.g. Amabile, et al., 1996; Sternberg \& Lubart, 1999; Torrance, 1981). Certain aspects of creative production depend on ideas about a single creator (Negus \& Pickering, 2000). Creativity is influenced by the context and is embedded in and specific to people's everyday lives (Negus, 1998; Gl_aveanu, 2010, Tang, 2019). Individualized creativity is currently under-explored in the literature of cultural and creative industries focusing mainly on the spatiality of creative businesses and collective creativity associated with an entrepreneurial context (e.g. Vallance 2014; Gong and Hassink 2016; Tang, 2019).

Creativity is not limited to personal aspects, and those who focus on its social dimension create a serious challenge to the credibility of traditional boundaries of the "individual creativity" concept (JohnSteiner 2000; Watson, 2007). Social creativity is defined as the everyday, ordinary, unplanned, and collective creative acts of people, and involves the concepts that have already been mentioned. Purser and Montuori (1999) use the term "sustained creativity" to describe creativity that occurs through normal activities. They believe that maintaining and sustaining the everyday creativity leads to promotion of existing environments. Richards (2007) defines "Everyday creativity" as one of the key concepts that includes the average, small activities instead of concentrating on ideas that make fundamental changes or bring about great innovations.

According to Fischer (1995), "Much human creativity is social, arising from activities that take place in a social context in which interaction with other people and collective knowledge are essential contributors." He believes that the emergence of social creativity requires the incentives of the actors to become active colleagues, to bring their knowledge into discourse, and to develop ideas in partnership with other people involved in the process(Fischer, 1995). The incentives to 
express ideas through participation and exchanging experiences is the necessary condition of social creativity (Sonnenburg, 2004; Burns et al., 2015). Participation occurs when the issue is individually and socially meaningful for the involved actors and requires a supporting tradition and paradigm that can provide the basis of creativity (Sannino \& Ellis, 2014). The system of beliefs and values called "the culture of participation" (Fischer \& Shipman, 2011) allows for prosperity of creativity, while admission of the historical context (Ville, 2011), the sociocultural (Fischer \& Shipman, 2011; Watson, 2007), and political (Burns, et al., 2015) structures create a context in which creative experiences take place. The interactions between people and the expression of ideas result in shared experiences.

Social creativity is a communicative process influenced by conscious and unconscious actions of individuals. The governing paradigms and beliefs of the community provide an idealized situation for consideration of different ideas and the engagement of actors in creative experiences. Innovative experiences occur in the participatory platforms where the basis is provided for the sociocultural involvement of people. Fig. 1 shows how social creativity is generated from contextual factors and mutually related to social experiences both through conscious and unconscious actions.

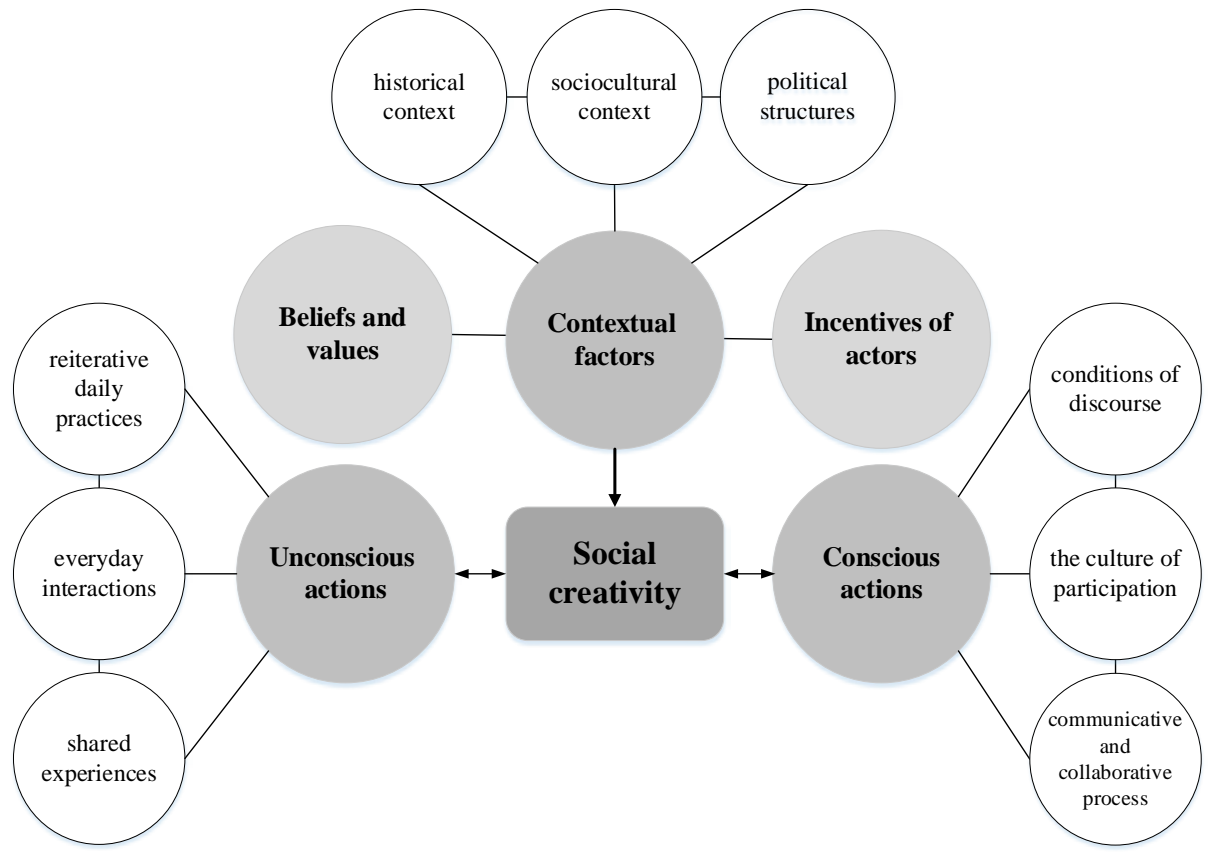

\section{Social Creativity as a Means of Place (Re)production}

Social Creativity as an outcome of the interactions between people and their surrounding environment is mentioned in different studies (Richards, 2007, Runco, 2007; Salomon, 1993; Watson, 2007). The physical environment and its characteristics are important in fostering the individual and collective creativity (Drake, 2003; Perry-Smith \& Shalley, 2003). John-Steiner (2000) believes that public spaces and their
Figure 1. The relationship between factors effective on social creativity 
Social Creativity and Place (Re)production: Tarbiat Pedestrian Route in Tabriz, Iran

forms are results of common thinking, shared interests, and collaborative efforts in meaningful relationships, but little is known about how urban places, in which different actors (such as designers, residents and arts performers) work and/or live, matter in creative work. Ho (2009) and Drake (2003) believe it is not clear to what extent these places can act as catalysts for individualized and socialized creativity.

Design activism (Fischer, 2005; Thorpe, 2008) based on the active role of people provides a basis for creative experiences (Marchart, 1998). Promoting social creativity in urban design is embedded in activism, which involves motivating actions, mobilizing stakeholders involved in the project, and creating a competitive environment (Markusen, 2011). Adopting social creativity in urban design changes the approach from "designing 'for' the community" to "designing 'with' the community" and eventually creates opportunities for communities to "design 'by' themselves" (Meroni et al., 2013). Design by people, or so-called DIY (do it yourself) urban design (Douglas, 2014), emphasizes the unauthorized alterations made in urban spaces and considers them as a symbol of collective creativity.

Place (re)production also refers to a collaborative process by which the public realm is shaped according to shared values. Placemaking occurs through repetition of everyday activities in space, sharing everyday experiences and cultural practices. Drawing on urban creative placemaking research (Drake, 2003; Lloyd, 2006; Ho, 2009; Rantisi and Leslie, 2010; Tang, 2019), it is important to highlight social creativity and the manner in which it constitutes a part of place production.

Designers accomplish expert-oriented (re)production of places through planned processes (Fig. 2), which are categorized into several processes including design, development, consumption, and management (Carmona, 2015). Lefebvre (1991) refers to "enabling citizens to participate in the production of place" as a way of socializing and expressing creativity. He defends citizens' right to participate - the right to access and influence the decisions and processes that generate space - and citizens' right to appropriation - the right to access, occupy and use space - as well as the right to create new space that responds to their emotions, dreams, and needs.

Applying social creativity in urban design requires a discourse-based process to create a framework for the participation and collaboration of involved actors. Conscious (re)production of place in urban design is a process that takes place through corresponding processes of design, management, and development. Furthermore, unconscious actions of people in their everyday lives create reiterative social practices that shape the interactions among individuals and lead to shared experiences. Thus, (re)production of places is also a routine and daily process, which takes place through daily practices, everyday interactions, sharing experiences, and communicating. 


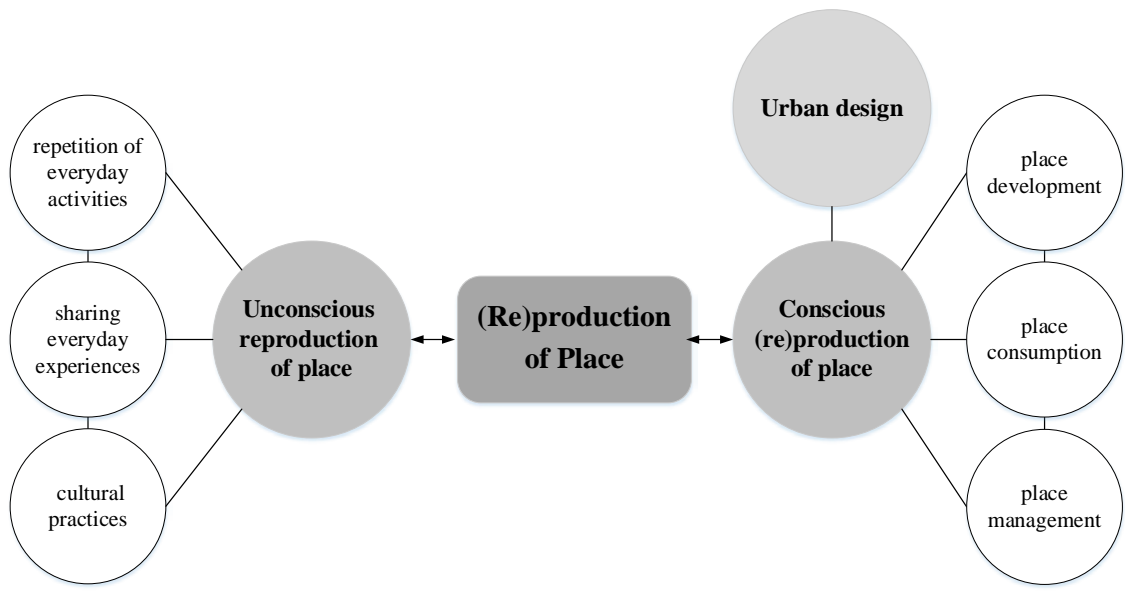

Figure 2. The conscious and unconscious factors in (re)production of place

The following conceptual map indicates the relationship between the criteria of social creativity with the criteria of place (re)production (Fig. 3 ). The effective criteria of the (re)production of place is divided into three main domains of "contextual factors", "conscious (re)production", and "unconscious (re)production". The mechanism of creative (re)production of place in urban design has both conscious and unconscious aspects. The conscious level can provide the basis for the unconscious (re)production of place. These levels will be addressed in Tarbiat pedestrian route using qualitative techniques.

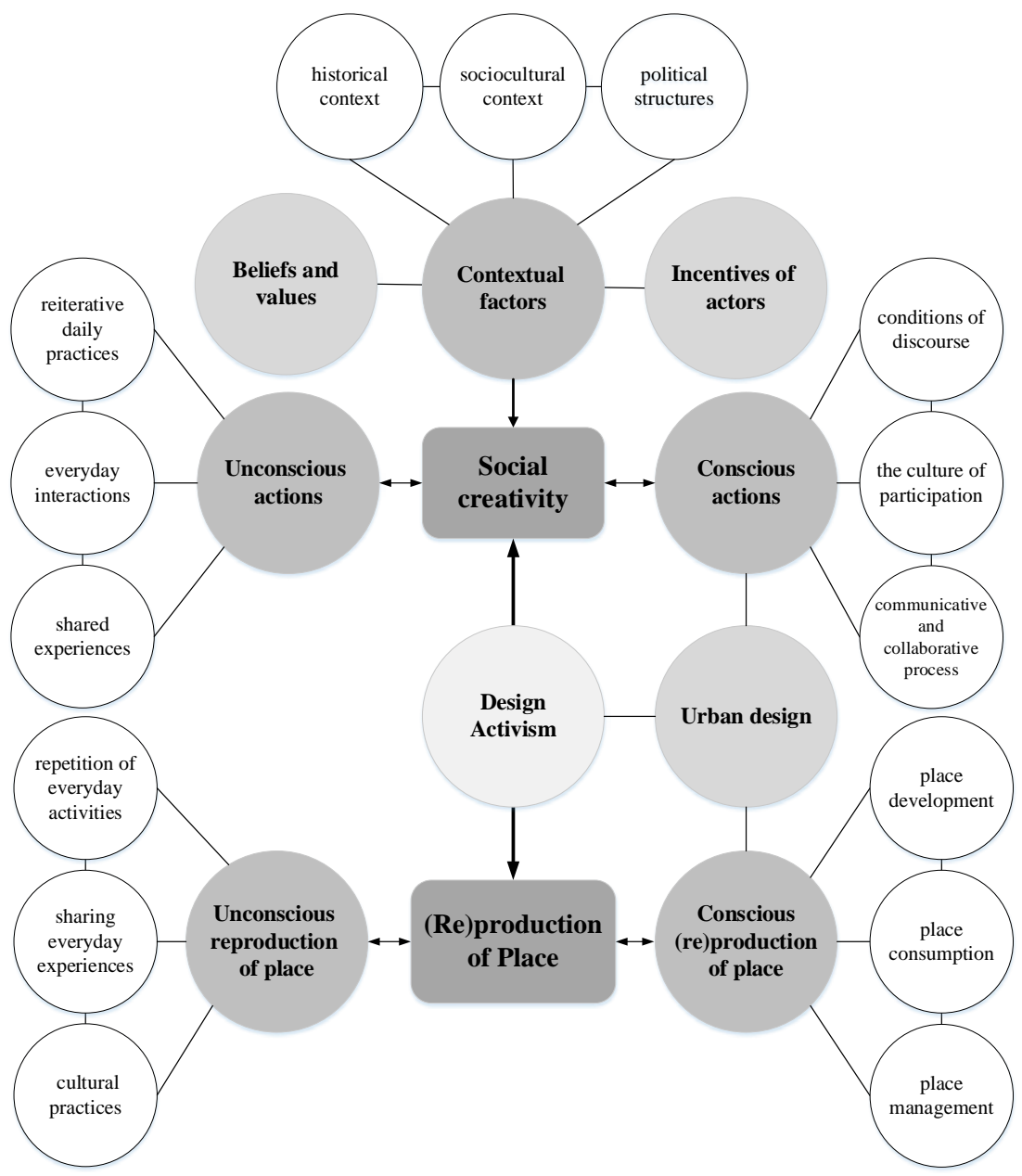

Figure 3. Developed relationship between the criteria of social creativity and the (re)production of place in urban design 
Figure 4. The location of the historical centre of Tabriz (the 8th district of Tabriz municipality)

Figure 5. The location of Tarbiat pedestrian route in city centre of Tabriz
Social Creativity and Place (Re)production: Tarbiat Pedestrian Route in Tabriz, Iran

\section{THE CASE STUDY: TARBIAT PEDESTRIAN ROUT}

Tabriz, with a population of 1,611,000 in 2020 and an area of 237.45 $\mathrm{km} 2$, is the third largest city in the country after Tehran and Mashhad. It is the capital of East Azerbaijan province and was historically selected as the capital of Iran in Safavid dynasty (1500 AH).

The case under study, Tarbiat pedestrian route, is located in the $8^{\text {th }}$ district of Tabriz municipality and links the central core of the city through Imam Khomeini Street (Main Street) to the Tabriz Bazaar. This street is one of the most important commercial, cultural, and historical centers of Tabriz. Valuable buildings and facilities such as the Tabriz Ark, historical Mosque of Ostad -Shagerd, Tabriz Municipality and Time Square (Maidan-e Saat) are in or relatively close to this street.
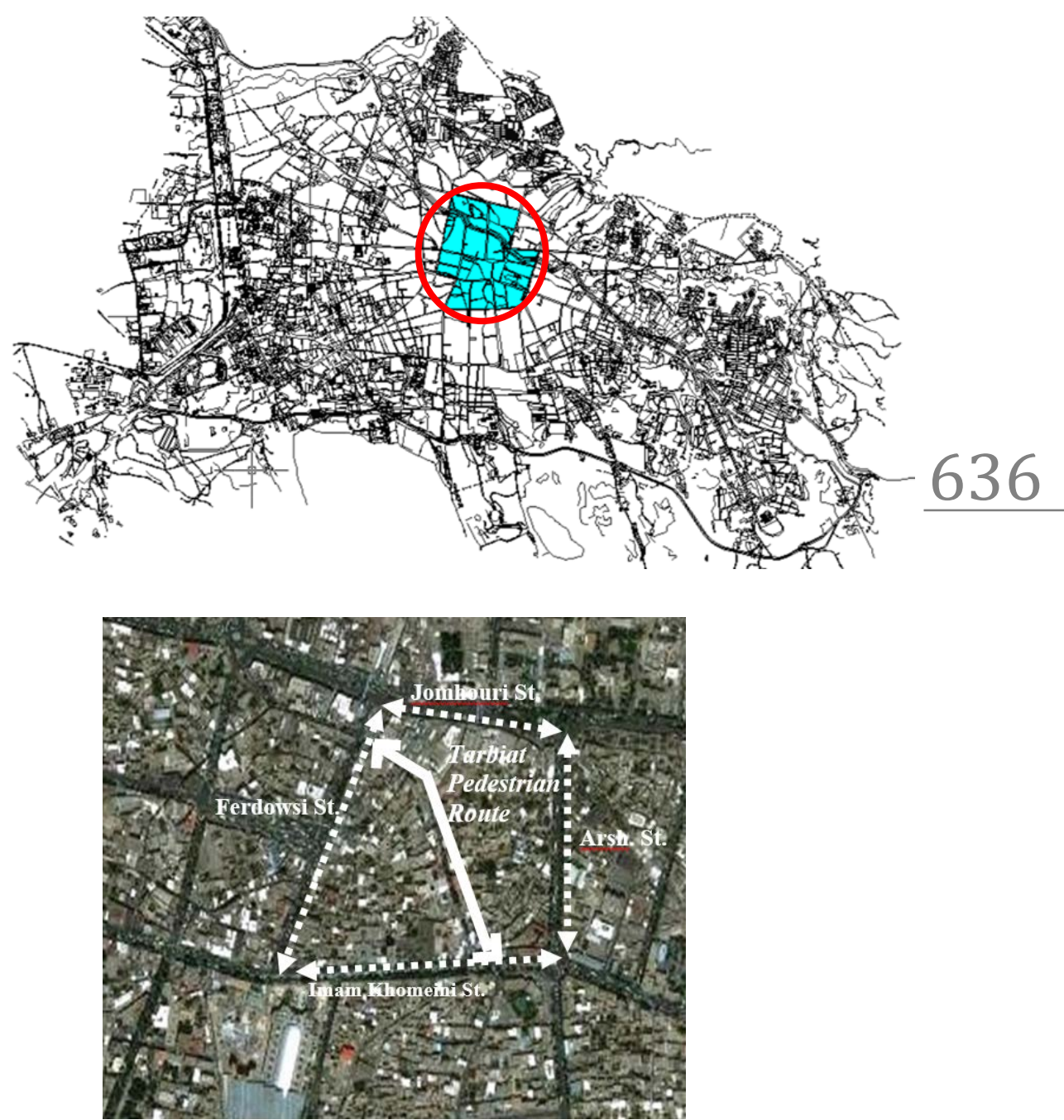

The initial interventions in Tarbiat Street were undertaken in 1993, through which the eastern part of the street turned into a pedestrian route with commercial and recreational functions, but it lost its spatial quality over two decades, and several problems appeared in this area. Therefore, in 2011, "organization and improvement of the Tarbiat pedestrian route" project was established by the "Renovation Centre of 
Tabriz Municipality ". Regeneration of the Tarbiat pedestrian route in Tabriz has been implemented in recent years and acclaimed by authorities as a creative attempt for (re)production of place (Abbaszadeh \& Tamari, 2013; Kalantari, SoltanMoahamadlou \& SoltanMoahamadlou, 2017).

Historical context: The route was formed between 1929 and 1932 to facilitate the accessibility between the Nobar and Digbashi historic gates and was named Tarbiat after the name of the mayor at the time, "Muhammad Ali Tarbiat." The impact of the historical constancy on the development of Tarbiat pedestrian route is very significant. The intrinsic features of Tarbiat Street as a place for pedestrian activities are formed and evolved gradually over a 200-years period, from the Qajar dynasty on. The passage was expanded during the second Pahlavi period (1925-1979) due to the high level of pedestrian activity and changed to an important urban space in the historical context of Tabriz city (Esmaili Sangari, 2014; Zamani, 2008). In addition, the historical features of Tarbiat Street as part of the Silk Road and its location in the central part of Tabriz created a strong historical image for it.

Functional aspects: Tarbiat is a multi-functional commercial pedestrian street. The strategic location of the street in the central core of city, and its spatial and functional connections with the Tabriz Bazaar have helped in forming a commercial network. The following land use map from the Tabriz detailed plan shows that commercial activities are concentrated in the street and penetrate to the surrounding area. The multi-scale mixed land uses strengthens the economic role of the pedestrian street.

Physical context: Tarbiat is a relatively narrow street with old-style facades and special architectural pattern. The proper proportions and spatial enclosure are the distinguishing and identifying characteristics of Tarbiat Street. Regeneration of the old entrance makes a remarkable local symbol and identifies the physical limits of the place.
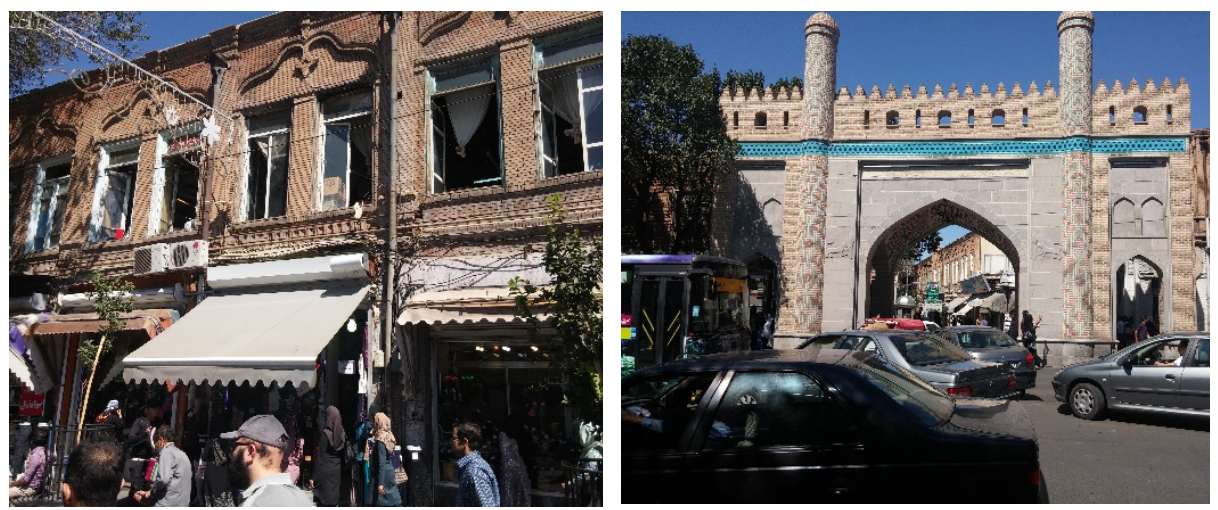

Social characteristics of Tarbiat: The local society is interested in Tarbiat as it provides the necessary facilities and amenities for individuals. Vicinity to the Tabriz Bazaar and the function of Tarbiat as an active pedestrian route invites different groups of people, specifically
Figures 6. Old-style facades and the special architectural pattern (left)

Figure 7. The entrance of Tarbiat pedestrian route, which is the regeneration of historical Nobar Gate (right) 
Figures 8 \& 9. The lighting and artworks are considered as creative elements and a part of the place identity (e.g. the stone benches engraved with the design of historical Qari Bridge)
Social Creativity and Place (Re)production: Tarbiat Pedestrian Route in Tabriz, Iran

the residents of adjacent and remote neighborhoods and creates social interactions.

Perceptual aspects: The perception of pedestrian in Tarbiat pedestrian route depends on their personal characteristics, walking times and visiting purposes. The physical settings like artworks and street lighting are the main contributors to enhancing the perception of users on Tarbiat followed by the vitality of street formed by various business types, outdoor performers, and other pedestrian activities. Also, preserving the historical identity during the revitalization project has influenced the perception of the pedestrians, especially constant users. Most regular pedestrians prefer to walk throughout Tarbiat path for its historical values and functional aspects which has distinctive meanings for users.
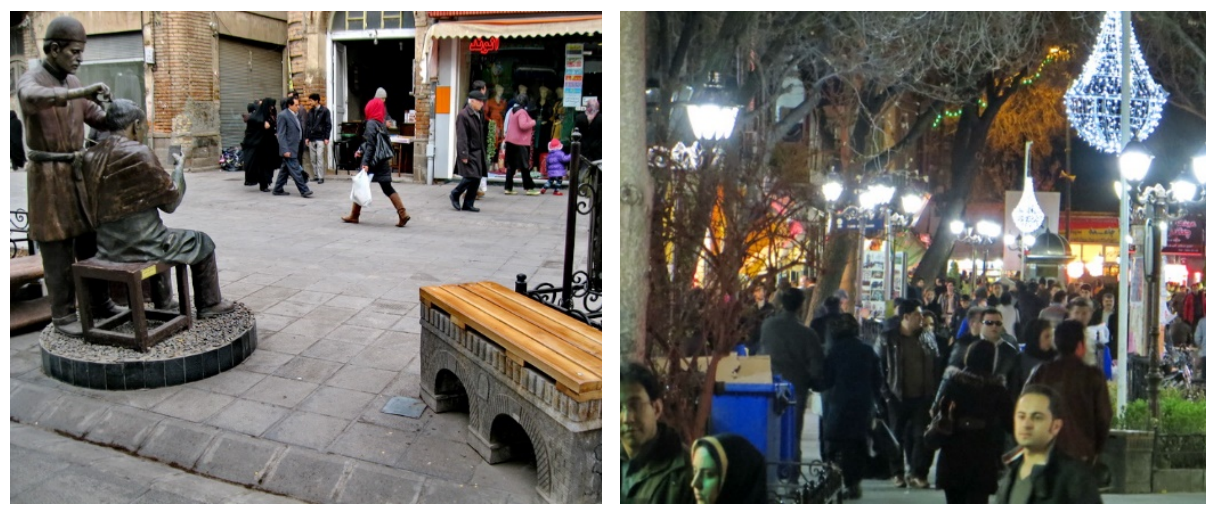

\section{THE METHOD}

Qualitative research was performed from May to September 2019. Twenty-nine in-depth interviews were conducted with people involved in different levels of the planning and development of the place. Interviewee selection was accomplished through purposeful snowball sampling based on the common characteristics of the involved people at different stages of the project who played an effective role in the place (re)production process.

The interviews were unstructured and informal, and the interviewees could talk in depth about the Tarbiat pedestrian route including the history, the existing situation, the activities and interventions in the place, and the overall process of changes through time. The interviewees were non-randomly selected by snowball sampling method based on their participation in the planning phases of the project. Designers provided registered information regarding participants. Selected participants were concerned about the project, actively participated in workshops, tried to make their voices heard and influenced the design processes. The participatory workshops solved the conflicts between actors and resulted in creative solutions for some problems through guidance of designers. The information about the composition of interviewees including the resident/user, gender and age of the interviewees was balanced to maximize diversity (Table 1). 
Table 1. The attributes of the interviewees

\begin{tabular}{|l|l|}
\hline Participants & Gender \\
\hline Resident (21 persons) & Female (6), Male (7) \\
\hline Constant User (5 persons) & Female (4), Male (3) \\
\hline Temporary User (3 persons) & Female (2), Male (7) \\
\hline
\end{tabular}

The methodology was based on thematic Content Analysis (TCA) using Computer-Aided Qualitative Data Analysis Software (CAQDAS) Atlas.ti. 06. ATLAS.ti is acknowledged as an essential tool that facilitates researchers' ability to undertake well-organized, systematic, effective and efficient data analysis in many studies (e. g. Lu \& Shulman, 2008; Friese, 2011; Rambaree \& Faxelid, 2013). The software renders qualitative data more visual, is portable, and facilitates the processes of segmenting, categorizing, annotating, retrieving, and searching within and across documents and categories. Based on the process of data analysis in Atlas.ti, six steps were distinguished as follows:

- Creating hermeneutic units (HU),

- Assigning primary documents,

- Discovering relevant contents,

- Creating codes and memos,

- Building theory by interlacing contents to networks, and

- Writing the results.

\section{The Content Analysis of Interviews}

Application of the used software consisted of coding documents, extracting key concepts, and constructing sub-themes and themes. Table 1 summarizes the results of the interviewees' viewpoints on the contextual factors. Based on the analysis, the contextual factors are categorized as follows: 1) context of place, 2) the role of actors, 3) political forces and power relations, 4) traditions and paradigms, and 5) incentives.

The interviewees believed that the designers of Tarbiat project had a conservative viewpoint about the values of Tarbiat pedestrian route, and thus the plan was in accordance with the status quo. Also, interventions of designers in the place were accompanied by the everyday lives of residents. The interviewees believe that the changes responded to their needs and solved the essential problems of the place. The findings revealed that the ruling paradigms and beliefs based on the implementable, enforceable, and gradual interventions according to the existing conditions attract different groups of people to the place and can lead to social creativity. Incentives of social creativity in the (re)production of place are closely associated with the power and influence of the people to express their opinions and play an active role in the process. The urban designers had an effective influence on the (re)production of place in Tarbiat by involving different stakeholders, explaining the benefits of the plan, and stimulating people's motivation. 
Social Creativity and Place (Re)production: Tarbiat Pedestrian Route in Tabriz, Iran

Understanding the benefits of changes created incentives for community participation in the process of transforming Tarbiat Street to a pedestrian route. The concerned and committed approach of designers throughout the negotiations reduced the power of urban administration over the place and activated people to play their role in the process. This attitude created trust among local actors mobilized them and generated a platform for sustainable daily experiences.

Table 2. Summary of Interviewees' views on theme "Contextual factors"

\begin{tabular}{|c|c|c|}
\hline Main Codes & Key Concepts & Sub-themes \\
\hline $\begin{array}{l}\text { Historical and strategic location, historical } \\
\text { buildings belonging to Qajar period, } \\
\text { founded by Mohammad Ali Tarbiat }\end{array}$ & Historical context & Context of place \\
\hline $\begin{array}{l}\text { Functional connections with Tabriz } \\
\text { bazaar, variety of functions, diverse } \\
\text { boutiques and shopping centers }\end{array}$ & $\begin{array}{l}\text { Functional and } \\
\text { economical context }\end{array}$ & \\
\hline $\begin{array}{l}\text { Physical enclosure, desirable proportions, } \\
\text { specific entering gates, valuable façades }\end{array}$ & $\begin{array}{l}\text { Physical and spatial } \\
\text { context }\end{array}$ & \\
\hline Diversity of social groups & $\begin{array}{lll}\text { Social features of } \\
\text { users }\end{array}$ & \\
\hline $\begin{array}{l}\text { The active role of urban designers in the } \\
\text { project, the effective role of the Cultural } \\
\text { Heritage Organization in preserving the } \\
\text { values of place during transformation }\end{array}$ & $\begin{array}{l}\text { The active role of the } \\
\text { urban designer }\end{array}$ & f actors \\
\hline $\begin{array}{l}\text { Values based on the revitalization of a } \\
\text { historical place }\end{array}$ & $\begin{array}{ll}\text { Common } & \text { values } \\
\text { among actors }\end{array}$ & \\
\hline $\begin{array}{l}\text { Feeling responsibility to place, trust of } \\
\text { people in designers }\end{array}$ & $\begin{array}{l}\text { The active role of the } \\
\text { residents }\end{array}$ & \\
\hline $\begin{array}{l}\text { Effective role of the NGOs in conserving } \\
\text { the historical context, the active role of } \\
\text { the public institutions }\end{array}$ & $\begin{array}{l}\text { The power and } \\
\text { influence of NGOs and } \\
\text { public institutions }\end{array}$ & $\begin{array}{ll}\text { Political } & \text { forces } \\
\text { and } & \text { power } \\
\text { relations } & \\
\end{array}$ \\
\hline $\begin{array}{l}\text { Adaptation of the plan to the status quo, } \\
\text { feasible and enforceable interventions }\end{array}$ & Beliefs about the plan & $\begin{array}{l}\text { Traditions and } \\
\text { paradigms }\end{array}$ \\
\hline $\begin{array}{l}\text { Gradual and step-by-step actions, taking } \\
\text { advantage of past experiences, taking } \\
\text { advantage of global experiences }\end{array}$ & $\begin{array}{l}\text { Patterns } \\
\text { intervention }\end{array}$ & \\
\hline $\begin{array}{l}\text { Application of rules for protection of } \\
\text { historical buildings, protecting identical } \\
\text { elements, designing new identical } \\
\text { elements }\end{array}$ & $\begin{array}{lr}\text { Conservation of } \\
\text { traditional and } \\
\text { historical identity }\end{array}$ & \\
\hline $\begin{array}{l}\text { Economic benefits of interventions to } \\
\text { people, overcoming the fear of loss }\end{array}$ & $\begin{array}{l}\text { Explaining the } \\
\text { benefits of plan and } \\
\text { motivating people by } \\
\text { designers }\end{array}$ & Incentive \\
\hline $\begin{array}{l}\text { Changing decorations, improving the } \\
\text { interior space of shops, changing the } \\
\text { facades }\end{array}$ & $\begin{array}{l}\text { Understanding the } \\
\text { benefits of changes by } \\
\text { people }\end{array}$ & \\
\hline
\end{tabular}

Based on the content analysis of the interviews, the main criteria explaining social creativity in the design process of the Tarbiat project are 1) context-oriented approach, 2) regenerative actions, 3) identityoriented approach, 4) innovation, 5) beautification, and 6) creating 
meaning. Table 2 summarizes the interviewees' perspectives on the concept of "social creativity."

Table 3. Summary of Interviewees' points on "Social creativity"

\begin{tabular}{|l|l|}
\hline Main Codes & Key Concepts \\
\hline $\begin{array}{l}\text { Considering the historical and cultural context, considering the } \\
\text { daily lives of residents, considering the needs and desires of } \\
\text { different groups of users }\end{array}$ & $\begin{array}{l}\text { Context-oriented } \\
\text { approach }\end{array}$ \\
\hline $\begin{array}{l}\text { Regenerating the past values, e.g., the historical gates and } \\
\text { traditional activities, representing memories }\end{array}$ & Regenerative actions \\
\hline $\begin{array}{l}\text { Renovation of buildings, using identical elements, conservation } \\
\text { of historical buildings }\end{array}$ & Identity building \\
\hline $\begin{array}{l}\text { Making difference through design, shared Initiatives, } \\
\text { converting constraints to opportunities }\end{array}$ & Innovation \\
\hline $\begin{array}{l}\text { Using public art, improving urban furniture, improving } \\
\text { environmental quality }\end{array}$ & Beautification \\
\hline Providing meaningful elements in the place & Creating meaning \\
\hline
\end{tabular}

The context-oriented and regenerative actions of designers positively impacted residents and increased the potential for everyday creative activities and collaborative bottom-up actions, e.g., restoring and lighting building facades, changing decorations, and improving the interior spaces of shops. Furthermore, the quality of place was improved through meaningful elements, e.g., equipping the place to the furniture and installing sculptures of traditional Tabriz businesses.

The formal and conscious place (re)production involves professional actions that enact changes in the place through a set of interventions in the physical, functional, and socio-cultural contexts. The effective phases of the conscious (re)production of the Tarbiat pedestrian route include 1) preparing the plan; 2) resolving conflicts between actors, creating conditions of discourse, and building consensus; 3) inviting the participation of actors; 4) implementing the plan; and 5) managing and developing the place. Table 3 summarizes the interviewees' viewpoints on the "conscious (re)production of place."

The active role of Tarbiat pedestrian route designers resolved conflicts, facilitated interaction among stakeholders, and attracted public participation, thereby providing the primary steps for resident participation and the opportunity for people to express their ideas and inspirations about the plan. Informing the residents before implementation of the plan and paying attention to their opinions indicates the responsibility of administrative authorities. The continuity of the conscious actions in maintaining the place led to building trust among the users and created a sense of responsibility in people. Face-toface meetings with people and making all voices heard significantly impacted public participation in expressing their ideas and led to a constructive relationship among the stakeholders. 
Social Creativity and Place (Re)production: Tarbiat Pedestrian Route in Tabriz, Iran

Table 4. Summary of Interviewees' points on "Conscious (re)production of place"

\begin{tabular}{|c|c|c|}
\hline Main Codes & Key Concepts & Sub-themes \\
\hline $\begin{array}{l}\text { Interest and attention of the } \\
\text { designers to the place }\end{array}$ & $\begin{array}{l}\text { Formation of the } \\
\text { incentives }\end{array}$ & \multirow[t]{3}{*}{$\begin{array}{l}\text { Preparing the } \\
\text { plan }\end{array}$} \\
\hline $\begin{array}{l}\text { Assessment of needs, feasibility of } \\
\text { the plan }\end{array}$ & Recognition of the place & \\
\hline $\begin{array}{l}\text { Integrity of place with its periphery, } \\
\text { preserving historical identity, } \\
\text { preparing walking facilities }\end{array}$ & $\begin{array}{l}\text { Defining the design goals, } \\
\text { ideas, and solutions }\end{array}$ & \\
\hline $\begin{array}{l}\text { Superiority of the collective benefits } \\
\text { over individual benefits, resolving } \\
\text { the conflicts between residents and } \\
\text { urban authorities }\end{array}$ & $\begin{array}{l}\text { Resolving } \\
\text { between actors }\end{array}$ & \multirow{2}{*}{$\begin{array}{l}\text { Resolving } \\
\text { conflicts and } \\
\text { consensus } \\
\text { building } \\
\text { among actors }\end{array}$} \\
\hline $\begin{array}{l}\text { Negotiation with the Cultural } \\
\text { Heritage Organization to take part in } \\
\text { the plan, inter-organizational } \\
\text { cooperation }\end{array}$ & Consensus building & \\
\hline $\begin{array}{l}\text { Informing residents through formal } \\
\text { announcements and letters, paying } \\
\text { attention to the residents' opinions }\end{array}$ & $\begin{array}{l}\text { Informing residents and } \\
\text { building trust }\end{array}$ & \multirow[t]{3}{*}{$\begin{array}{l}\text { Inviting the } \\
\text { participation of } \\
\text { actors }\end{array}$} \\
\hline $\begin{array}{l}\text { Public hearings, considering ideas of } \\
\text { residents }\end{array}$ & $\begin{array}{l}\text { Participation of actors in } \\
\text { expressing their ideas }\end{array}$ & \\
\hline $\begin{array}{lr}\text { Face-to-face meetings } & \text { with } \\
\text { administrators, establishing positive } \\
\text { and relationships } \\
\text { stakeholders }\end{array}$ & $\begin{array}{l}\text { Interactive and } \\
\text { collaborative approach }\end{array}$ & \\
\hline $\begin{array}{l}\text { Gradual changes, improving the } \\
\text { infrastructure }\end{array}$ & $\begin{array}{l}\text { The intensity of physical } \\
\text { interventions }\end{array}$ & $\begin{array}{l}\text { Implementing } \\
\text { the plan }\end{array}$ \\
\hline $\begin{array}{l}\text { Maintaining pedestrian movement in } \\
\text { the area, developing and enhancing } \\
\text { different functions }\end{array}$ & $\begin{array}{l}\text { Sustained development } \\
\text { efforts }\end{array}$ & \multirow[t]{4}{*}{$\begin{array}{l}\text { Managing and } \\
\text { developing the } \\
\text { place }\end{array}$} \\
\hline $\begin{array}{lll}\begin{array}{l}\text { Economic } \\
\text { visitors }\end{array} & \text { prosperity } & \text { increases } \\
\end{array}$ & Economic prosperity & \\
\hline Creating a flexible space & The flexibility of changes & \\
\hline $\begin{array}{l}\text { Management of place, monitoring } \\
\text { changes }\end{array}$ & $\begin{array}{l}\text { Sustained management } \\
\text { and maintenance }\end{array}$ & \\
\hline
\end{tabular}

A process of informal, bottom-up, and unconscious (re)production of place is also identifiable in the Tarbiat project. Table 4 summarizes the interviewees' viewpoints about the unconscious (re)production of place, which is prepared in the form of the key concepts achieved from the codes and the attained sub-themes and themes. The main stages of unconscious (re)production of place are 1) being accustomed to the place, 2) ongoing places consumption, and 3) establishing a stable relationship with the place.

The process of unconscious (re)production of place begins with familiarity with the place and its recognition through daily practices. For interviewees, the Tarbiat pedestrian route is a unique and memorable place regarded as a destination rather than a passage. The interviewees believe that professional interventions have boosted the social life of Tarbiat pedestrian route, provided a suitable condition for communicative and recreational activities, and changed it to a dynamic and vibrant place. Diverse activities, functions, and events attract different groups of people to the place, thus creating vitality. 
Table 5. Summary of Interviewees' points on "Unconscious (re)production of place

\begin{tabular}{|l|l|l|}
\hline Main Codes & Key Concepts & Sub-themes \\
\hline $\begin{array}{l}\text { Historical continuity of changes in the minds } \\
\text { of people }\end{array}$ & Place continuity & $\begin{array}{l}\text { Being accustomed } \\
\text { to the place }\end{array}$ \\
\cline { 1 - 2 } $\begin{array}{l}\text { Social interactions, vitality, the order in the } \\
\text { layout of buildings, harmony of the facades, } \\
\text { proximity to the Bazaar, attractiveness and } \\
\text { functionality }\end{array}$ & $\begin{array}{l}\text { Specific features } \\
\text { of place }\end{array}$ & \\
\cline { 1 - 2 } $\begin{array}{l}\text { Individual and collective memories } \\
\text { Long-time residency, neighbourhood } \\
\text { relationships, shopping, sitting, meeting } \\
\text { friends, wandering around, having fun, } \\
\text { relaxing }\end{array}$ & $\begin{array}{l}\text { Repetitive } \\
\text { everyday } \\
\text { activities }\end{array}$ & $\begin{array}{l}\text { Ongoing } \\
\text { consumption } \\
\text { place }\end{array}$ \\
\cline { 1 - 2 } $\begin{array}{l}\text { Renovation of building frontages, renovation } \\
\text { of shops }\end{array}$ & $\begin{array}{l}\text { Changing space } \\
\text { by users }\end{array}$ \\
\cline { 1 - 2 } $\begin{array}{l}\text { Living around the place, unwillingness to } \\
\text { leave the place, returning to the place }\end{array}$ & $\begin{array}{l}\text { Sense } \\
\text { belonging to the } \\
\text { place }\end{array}$ & $\begin{array}{l}\text { Establishing } \\
\text { stable relationship } \\
\text { with the place }\end{array}$ \\
\cline { 1 - 2 } $\begin{array}{l}\text { Emotional, cognitive, and functional } \\
\text { attachment to the place }\end{array}$ & $\begin{array}{l}\text { Attachment to } \\
\text { the place }\end{array}$ \\
\hline
\end{tabular}

\section{RESULTS}

Tarbiat pedestrian route is simultaneously the product of gradual changes of place by people over time and interventions of designers. The gradual and step-by-step interventions in place aligned with bottom-up and unconscious actions of people lead to (re)production of place. Design, development, and management processes provide the basis for unconscious (re)production of place and the repeated everyday interactions and shared experiences. The emerging ordinary and sustainable creativities of people improve space into a living place. Therefore, the two levels of creative (re)production of place in the Tarbiat pedestrian route are identified as follows:

\section{Level 1: Conscious (re)production of place}

Preparing the plan: The plan of Tarbiat pedestrian route is based on the exact recognition of the status quo and the needs of residents, and thus provides a dynamic and vibrant context for people. Accurate recognition, executive viewpoint, and feasibility of the plan are influential to the formation of creative activities.

Resolving conflicts and consensus building among actors: The active role of urban designers in resolving conflicts and consensus building among stakeholders to achieve an agreement through a gradual process provides the basis of collaboration and interaction between participants, which is influential in proceeding the goals of conscious (re)production of place.

Involving the participation of actors: Participation of people in Tarbiat pedestrian route requires community-based socialization: trust building; 
mobilizing residents in expressing their ideas, desires, and opinions; and adopting a collaborative process. The formation of a Board of Trustees in Tarbiat project provides the basis for community participation and increases people's interest to express their ideas about the plan and make their voices heard, thus leading to spontaneous collective efforts that provide the stepping stone for social creativity in the (re)production of place.

Implementation of the plan: The gradual and step-by-step interventions that do not make fundamental changes in the everyday lives of people helps them accept the plan as part of the usual transformation of the place. The improvement and revitalization activities carried out alongside the infrastructural development of the place has a slow step-by-step procedure and thus becomes an integral part of the (re)production process.

Development of the place: Sustained development efforts in Tarbiat pedestrian route reinforces the economic prosperity of the area and thus, promotes the social life of people. Residents benefit economically from the developments, which happen in Tarbiat route and thus are motivated for more collective activities regarding changing the route.

Management and maintenance of the place: Maintaining security and continuously managing the development process are the key solutions for encouraging the presence of people. Although the safety of the place is not in a desirable condition, the activities of urban administration in managing Tarbiat pedestrian route affects the promotion of economic and social prosperity of the place, provides dynamic public space, and enhances vitality and social creativity in the area, which contributes to the (re)production of place.

\section{Level 2: Unconscious (re)production of place}

Being accustomed to the place: The process of unconscious (re)production of place in Tarbiat pedestrian route begins with place recognition during everyday life. Engaging the present residents and sustaining the history of changes in the minds of people provides the opportunity to create personal and collective memories and reproduce place through time. Formation of memories creates a sense of belonging and influences the (re)production of place in the minds of people.

Consumption of place: Tarbiat pedestrian route is continuously used through repetitive everyday experiences of users. This enhances social meanings, causes transformation of the place during everyday life, and affects the unconscious (re)production of place.

Establishing a stable relationship with place: A strong and stable relationship is established between the users and Tarbiat pedestrian route through recognition and everyday consumption of place. The relationship of people with Tarbiat pedestrian route leads to a sense of belonging and attachment to the place, which makes it distinct from other places. Table 5 displays the results regarding the levels and stages of "(re)production of place." 
Table 6. Experimental results of research about levels and stages of "(re)production of place"

\begin{tabular}{|c|c|c|}
\hline \multicolumn{2}{|c|}{ Main Levels of (re)production of place } & $\begin{array}{l}\text { Creative (re)production of place in } \\
\text { the Tarbiat pedestrian route }\end{array}$ \\
\hline \multirow{6}{*}{$\begin{array}{l}\text { Level } 1 . \\
\text { Conscious } \\
\text { (re)production } \\
\text { of place }\end{array}$} & Preparing the plan & $\begin{array}{l}\text { The economic and social incentives, } \\
\text { based on deep recognition of place, } \\
\text { adaptation of the plan to the context }\end{array}$ \\
\hline & $\begin{array}{l}\text { Resolving conflicts between } \\
\text { actors, creating conditions } \\
\text { of discourse, and building } \\
\text { consensus }\end{array}$ & $\begin{array}{l}\text { Negotiation and consensus among } \\
\text { stakeholders }\end{array}$ \\
\hline & $\begin{array}{l}\text { Involving the participation } \\
\text { of actors }\end{array}$ & $\begin{array}{l}\text { Active role of designers and } \\
\text { participation of people through } \\
\text { board of trusties }\end{array}$ \\
\hline & Implementation of the plan & $\begin{array}{lll}\begin{array}{l}\text { Gradual and } \\
\text { interventions }\end{array} & \text { long-term } \\
\end{array}$ \\
\hline & Development of place & Sustained development efforts \\
\hline & Management of place & $\begin{array}{l}\text { Sustained maintenance and } \\
\text { management of place }\end{array}$ \\
\hline \multirow{3}{*}{$\begin{array}{l}\text { Level } 2 . \\
\text { Unconscious } \\
\text { (re)production } \\
\text { of place }\end{array}$} & $\begin{array}{l}\text { Being accustomed to the } \\
\text { place }\end{array}$ & $\begin{array}{l}\text { Familiarity and continuity of the } \\
\text { mental image and memories of the } \\
\text { place }\end{array}$ \\
\hline & Consumption of place & $\begin{array}{l}\text { Everyday life and the occurrence of } \\
\text { iterative everyday activities }\end{array}$ \\
\hline & $\begin{array}{l}\text { Establishing a stable } \\
\text { relationship with place }\end{array}$ & $\begin{array}{l}\text { Deep emotional relationship } \\
\text { between people and place }\end{array}$ \\
\hline
\end{tabular}

The creative (re)production of place is a process in which all actors play roles. (Re)production of place is carried out by people through the guidance of active urban designers, along with the other public and private actors and urban administration. Creative (re)production of place is a gradual and long-term process requiring continuity of the professional activities. The gradual speed of interventions reproduces the place according to people's existing situations and lives. The urban design process in (re)production of place is a participatory and collaborative process based on the deep recognition of the status quo that provides strategies consistent with the context. The continuous development of place accompanied by its management and maintenance help people reconcile their lives with the pace of change. Place identity is preserved, and people are well acquainted with the (re)production process. Mental images and memories of the place are constant in the minds of users. Daily routines and repetitive experiences create place attachment and reinforce the emotional relationships between people and the place.

The results of the experimental research of Tarbiat pedestrian route shows that context is an important dimension of place flagged up during the fieldwork. Users considered place characteristics as fostering their creative practices. Moreover, a positive relationship between collaborative creative works and design activities were distinguished.

This is an empirical evidence supporting the theorizing of Markusen (2011) that the potential of creative production is shaped by physical elements including historical, socio-cultural and political context. While public participation was not an object of analysis in this research, the 
empirical data shows that the role of live-work arrangements has positive impacts on social interactions with the local community. There are also important place-specific elements implicated in the creative reproduction processes.

The preceding research of Markusen and Gadwa (2010) under the title of creative placemaking and the creative city theories raised by Florida (2002) and Landry (2012) focus on the practice of individual creativity to create high-quality places. In the case of Tarbiat route, the ongoing and flexible urban regeneration program together with communitybuilding motives led to consistent improvement by professional designers and artists, and establishment of a platform for building creative ideas in the form of art works, events and physical and functional changes. Tarbiat is therefore a case to extend our understanding of how creativity can impact place production. Tang (2019) emphasizes the role of context in social creativity and the fact that that social innovation can be a form of self-reliance needed for placemaking.

\section{CONCLUSIONS AND RECOMMENDATIONS}

Interdisciplinary analyses have identified the context of a place as a critical factor in developing creativity, but little attention has been paid to application of the concept of social creativity in the placemaking process. This study argues that social creativity is one of the effective factors in reproducing place in the urban design process. The research proposes a deeper concept of creativity in urban design that goes beyond individualistic and elitist views and is further inspired by sociological approaches like Gerhard Fischer's (1995, 2004, 2005, 2011, $2015)$ and Teresa Amabile $(1995,1996)$ studies on social creativity and its application in design fields.

The process of (re)production of place in Tarbiat pedestrian route represents an interaction between the conscious level of (re)production of place through urban design and the unconscious level of (re)production through the everyday shared experiences of people. Gradual expert-oriented interventions based on the potential of Tarbiat pedestrian route create an appropriate context for mobilizing actors and bringing them together. The conscious interventions are effective in improving social creativity and unconsciously (re)produce the place through the formation of bottom-up everyday interactions and creative experiences.

A few interviewees indicated that locality stimulates and manifests the expressions of creativity through its visual environment. The placebased socio-cultural networks and activities contribute to their creative work and inspiration. While this echoes Drake's (2003) theory on the relationship between place-based elements and socialized creativity, the data suggests that the design approach to the management of creative production of places plays a crucial role in shaping the milieu and orientation of those places, and the many ways in which people express 
their creative work. These findings also indicate that designers can influence the viability of particular types of artistic production within its place as actors. In the case of Tarbiat pedestrian route, the design practices manifest a tendency toward the promotion of conscious activities, economic viability, and bureaucratic principles, rather than facilitating creative processes and growing contemporary art. The design policy promotes civic values through enforcing artwork inspired by designers and managers experience in living and interacting with the local residents, and by their contacts with place-based visual materials. This allows creative residents to create artworks with strong placespecific elements.

Unconscious actions are important as a starting base, as with the placebased social networks and the live-work arrangements. Equally important, is the design approach to regeneration practices that affects the manner in which users relate their own production and identity to the locality as a production place. While this research mainly studies social creativity in various aspects, it does not focus on sub-sectors of the creative industries. How do different creative workers respond to a place? How are their work processes and individual creativity tied to dissimilar configurations of place? Further research would be useful to investigate these questions, especially as we know some of our understanding of creative production is closely linked to the knowledge of the design processes and the elements of place. Identifying these characteristics enables scholars and officials to learn the factors that influence the approach through which arts and cultural production base are developed.

\section{ACKNOWLEDGEMENTS/NOTES}

This research is extracted from a research project entitled: "Exploring placemaking principles in urban design based on social creativity approach" that has been done in the Faculty of Urban Planning of the University of Tehran.

\section{CONFLICT OF INTERESTS}

No conflict of interest was declared by the authors.

\section{FINANCIAL DISCLOSURE}

The authors declared that this study has received no financial support.

\section{ETHICS COMMITTEE APPROVAL}

Ethics committee approval was not required for this article.

\section{LEGAL PUBLIC/PRIVATE PERMISSIONS}

In this research, the necessary permissions were obtained from the relevant participants (individuals, institutions, and organizations) during the survey and in-depth interviews. 
Social Creativity and Place (Re)production: Tarbiat Pedestrian Route in Tabriz, Iran

\section{REFERENCES}

Akin, Ö. (1978). How do architects design? In J-C Latombe (Eds.). Artificial Intelligence and Pattern Recognition in Computer-Aided Design (pp. 65-104). North Holland.

Abbaszadeh, SH. and Tamari, S. (2013). Investigating the contributing factors on improving the spatial quality of pedestrian routes in order to increase the level of social interactions. Case study; Tabriz and Valiasr pedestrian routes, Journal of Urban Studies, 18, 1-10 (In Persian).

Amabile, T. M., Conti, R., Coon, H., Lazenby, J., \& Herron, M. (1996). Assessing the work environment for creativity, Academy of Management Journal, 39, 1154-1184.

Barlow, C. A. (2000). Deliberate insight in team creativity, Journal of Creative Behaviour, 34(2): 101-117.

Bourdieu, P. (1993). The field of cultural production. Columbia University Press.

Burns, T. and Corte, U. and Machado des Johansson, N. (2015). The sociology of creativity: PART II: Applications: The socio-cultural contexts and conditions of the production of novelty, Human Systems Management. 34, 263-286.

Carmona, M. (2015). Re-theorizing contemporary public space: a new narrative and a new normative, Journal of Urbanism: International Research on Placemaking and Urban Sustainability, 8(4), 373-405.

Csikszentmihalyi, M. (1996). Creativity - Flow and the Psychology of Discovery and Invention, HarperCollins Publishers, New York, NY.

Douglas, G. C. (2014). Do-it-yourself urban design: The social practice of informal "improvement" through unauthorized Alteration, City \& Community, 13, 5-25.

Drake, G. (2003). This place gives me space': place and creativity in the creative industries, Geo forum, 34(4), 511-524.

Esmaili Sangari, H. (2014). Strategies for the revival of historical contexts as the identical urban values. Case Study: The Historical Tarbiat Rout in Tabriz, Journal of Urban Management. 13(37), 35-56 (In Persian).

Fischer, G. (2014). Learning, Social Creativity, and Cultures of Participation, University of Colorado Boulder.

Fischer, G. and Shipman, F. (2011). Collaborative Design Rationale and Social Creativity in Cultures of Participation, Human Technology: An Interdisciplinary Journal on Humans in ICT Environments (Special Issue on Creativity and Rationale in Software Design), 7(2), 164-187.

Fischer, G., Giaccardi, E., Eden, H., Sugimoto, M., \& Ye, Y. (2005). Beyond Binary Choices: Integrating Individual and Social Creativity, 
International Journal of Human-Computer Studies (IJHCS) Special Issue on Computer Support for Creativity (E.A. Edmonds \& L. Candy, Eds.), 63(4-5), 482-512.

Fischer, G. (2004). Social Creativity: Turning Barriers into Opportunities for Collaborative Design, $8^{\text {th }}$ Conference on Participatory Design (PDC'04), 27-31 July, Computer Professionals for Social Responsibility (CPSR), pp. 152-161, Toronto.

Fischer, G. (1995) [2005]. Social Creativity: Making All Voices Heard, Proc. Human Computer Interaction International Conference (HCI 2005), Las Vegas, USA.

Florida, R. (2002). The Rise of the Creative Class and How It's Transforming Work, Leisure, Community and Everyday Life, Basic Books.

Gero, J. S. (1990). Design Prototypes: A Knowledge Representation Schema for Design, AI Magazine, 11(4), 26-36.

Gong, H., and Hassink. R. (2016). What Drives the Geographies of Creative Industries? From Literature Review to Research Agenda. Papers in Innovation Studies, Paper no. 2016/9, Lund University.

Hartley, J. (2005). Creative Industries. Blackwell Publishing.

Hemlin, S., Allwood, C. M., \& Martin, B. R. (Eds.). (2004). Creative knowledge environments, the influences on creativity in research and innovation. Edward Elgar.

Ho, K. C. (2009). The Neighborhood in the Creative Economy: Policy, Practice and Place in Singapore. Urban Studies, 46(5-6), 1187-1201.

Howkins, J. (2001). The creative economy. Penguin.

John-Steiner, V. (2000). Creative collaboration. Oxford University Press.

Kasl, E., Marsick, V. J., \& Dechant, K. (1997). Teams as learners, Journal of Applied Behavioral Science, 33, 227-246.

Kalantari K. H., SoltanMoahamadlou S. and SoltanMoahamadlou, N. (2017). Designing the pedestrian route and its impact on quality of life in the historical context of cities, A case study of Tarbiat pedestrian route in Tabriz, Journal of Iranian Architecture Studies (9), 156-174 (In Persian).

Landry, C. (2012). The creative city: a toolkit for urban innovators $\left(2^{\text {th }}\right.$ ed.). Earth scan.

Lawson, B. (2005). How designers think: The design process demystified (4th ed.). Architectural Press.

Lefebvre, H. (1991). The production of space. Blackwell.

Lloyd, R. (2006). Neo-Bohemia: Art and commerce in the post-industrial city. Routledge. 
Social Creativity and Place (Re)production: Tarbiat Pedestrian Route in Tabriz, Iran

Lu, C.-J., \& Shulman, S. W. (2008). Rigor and flexibility in computerbased qualitative research: Introducing the coding analysis toolkit, International Journal of Multiple Research Approaches, 2(1), 105-117.

Marchart, O. (1998). Art, Space and Public Sphere(s). Retrieved November 25, 2016.

Markusen, T. (2011). The disruptive aesthetics of design activism: enacting design between art and politics, Making Design Matter: Nordic Design Research Conference 2011, pp. 102-110, Helsinki.

Markusen, A. Gadwa, A. (2010). Creative placemaking. Markusen Economic Research Services and Metris Arts Consulting.

Meroni, A., Fassi, D., and Simeone, G. (2013). Design for social innovation as a form of designing activism. An action format. NESTA. Social Frontiers: The next edge of social innovation research.

Negus, K. (1998). Cultural Production and the Corporation: Musical Genres and the Strategic Management of Creativity in the US Recording Industry, Media, Culture \& Society, 20, 359-379.

Negus, K., and M. Pickering. (2000), Creativity and Cultural Production. Cultural Policy 6(2), 259-282.

Perry-Smith, J. E., and Shalley, C. (2003). The social side of creativity: Static and dynamic social network perspective, Academy of Management Review 28(1), 89-106.

Putnam, R.D. (1993). Making democracy work: Civic traditions in modern Italy. Princeton University Press.

Purser, R. E., and Montuori, A. (1999). Organizing as if creativity really mattered. In R. E. Purser and A. Montuori (Eds.), Social creativity ( $2^{\text {nd }}$ ed., pp. 313-357). Cresskill, NJ: Hampton Press.

Rambaree, K. and Faxelid, E. (2013). Considering Adductive Thematic Network Analysis with ATLAS.ti 6.2. In N. Sappleton (Ed.). Advancing Research Methods with New Media Technologies (pp.170-186). Hershey PA, USA, IGI Global.

Rantisi, N. M., and D. Leslie. (2010). Materiality and Creative Production: The Case of the Mile End Neighborhood in Montreal, Environment and Planning A: Economy and Space 42(12), 2824-2841.

Richards, R. (Ed.). (2007). Everyday creativity and new views of human nature: Psychological, social, and spiritual perspectives. American Psychological Association.

Robinson, A. G., and Stern, S. (1997). Corporate creativity: How innovation and improvement actually happen. Berrett-Koehler.

Runco, M. A. (2007). Creativity: Theories and themes: Research, development, and practice, Academic Press. 
Sannino, A. and Ellis V. (2014). Learning and collective creativity: Activity-theoretical and sociocultural studies, Taylor \& Francis/Routledge, pp. 198-215.

Salomon, G. (Ed.) (1993). Distributed cognitions: Psychological and educational considerations, Cambridge University Press.

Scott, A. J. (2006). Creative Cities: Conceptual Issues and Policy Questions, Journal of Urban Affairs 28(1), 1-17.

Sonnenburg, S. (2004). Creativity in Communication: A Theoretical Framework for Collaborative Product Creation, Creativity and Innovation Management (13), 254 - 262.

Sternberg, R., and Lubart, T. I. (1999). The concept of creativity: prospects and paradigms. In R. Sternberg (Ed.), Handbook of creativity (pp. 3-31). Cambridge, Cambridge University Press.

Tang, G., S. (2019). Putting creative production in place? Policy, creativity and artist villages, Creative Industries Journal, 13(1), 17-35.

Torrance, E. P. (1981). Toward the more humane education of gifted children. In J. G. Gowan, J. Khatena \& E. P. Torrance (Eds.), Creativity: Its educational implications. Kendall/ Hunt Publishing Company.

Thorpe, A. (2008). Design as activism: A conceptual tool. In Changing the Change (pp. 1523-1535). Turin.

Vallance, P. (2014). Creative Knowing, Organizational Learning, and Socio-Spatial Expansion in UK Videogame Development Studios, Geoforum (51), 15-26.

Ville, S. (2011). Historical Approaches to Creativity and Innovation. In L. Mann \& J. Chan (Eds.), Creativity and innovation in business and beyond: social science perspectives and policy implications (pp. 64-81). New York, Routledge.

Watson, E. (2007). Who or What Creates? A Conceptual Framework for Social Creativity, Research Article Human Resource Development Review, 6(4), $419-441$.

Zamani, B. (2008). Research Design Plan. Organizing the historicalcultural Tarbiat pedestrian Rout. Municipality of District 8 of Tabriz.

\section{Resume}

Behnaz Aminzadeh is a professor in Urban Design, College of Fine Arts, Faculty of Urban Planning in University of Tehran, IRAN. She received her Ph.D., in Urban Planning from University of NSW in Sydney, Australia, and M.Sc., in Urban Design from University of Tehran.

Razieh Rezabeigisani received her Ph.D. in Urban Planning and M.A. in Urban Design from University of Tehran, IRAN. She currently works as a university lecturer and researcher. 